\title{
PENERAPAN MODEL PEMBELAJARAN KOOPERATIF TIPE TAI (TEAM ASSISTED INDIVIDUALIZED) BERBANTUAN LKPD BERBASIS SAINTIFIK UNTUK MENINGKATKAN HASIL BELAJAR PADA SISWA KELAS VIII.2 SMPN 4 KOTA BENGKULU
}

\author{
${ }^{1}$ Farah Sal Sabillah, ${ }^{2}$ Nurul Astuty Yensy B, ${ }^{3}$ Syafdi Maizora \\ 1,2,3 Universitas Bengkulu, FKIP, Program Studi Pendidikan Matematika \\ e-mail : ${ }^{1}$ farahsalsabilah1296@ gmail.com, ${ }^{2}$ nurulastutyyensy@yahoo.com, \\ ${ }^{3}$ syafdiichiemaizora@unib.ac.id
}

\begin{abstract}
ABSTRAK
Penelitian ini bertujuan untuk mengetahui cara meningkatkan hasil belajar matematika dengan menerapkan model pembelajaran kooperatif tipe TAI berbantuan LKPD berbasis Saintifik. Jenis penelitian yang dilaksanakan adalah Penelitian Tindakan Kelas (PTK) dengan teknik pengumpulan data melalui nilai tes hasil belajar siswa setiap siklus. Instrumen hasil penelitian menunjukkan bahwa penerapan model pembelajaran kooperatif tipe TAI berbantuan LKPD berbasis Saintifik dapat meningkatkan hasil belajar matematika siswa kelas VIII.2 SMPN 4 Kota Bengkulu Subjek dalam penelitian ini adalah peserta didik kelas VIII.2 SMP Negeri 4 Kota Bengkulu tahun ajaran 2017/2018 yang berjumlah 35 orang terdiri dari 15 peserta didik laki-laki dan 20 peserta didik perempuan. Penelitian ini dilaksanakan dalam tiga siklus dari tanggal 19 Maret 2018 sampai dengan 14 Mei 2018. Peningkatan hasil belajar siswa dapat dilihat dari nilai rata-rata kelas tes siklus I, siklus II, dan siklus III secara berturut-turut 72,$38 ; 81,23 ; 85,83$ dengan ketuntasan klasikal pada siklus I, II, dan III secara berturut-turut yaitu $64,70 \%, 75,75 \%$, dan $82,85 \%$.
\end{abstract}

Kata Kunci : Model Pembelajaran TAI, LKPD, Pendekatan Saintifik, Hasil belajar

\begin{abstract}
This study aims to find out how to improve the results of mathematics learning by applying cooperative learning model TAI type assisted LKPD based Scientific. The type of research conducted is Classroom Action Research (PTK) with data collection techniques through the test results of student learning outcomes each cycle. The results showed that the application of cooperative learning model type TAI-aided LKPD based on Scientific can improve mathematics learning outcomes of students of class VIII.2 SMPN 4 Kota Bengkulu Subjects in this study were students class VIII.2 SMP Negeri 4 Bengkulu city 2017/2018 year that amounted to 35 people consisting of 15 male students and 20 female students. The study was conducted in three cycles from March 19, 2018 to May 14, 2018. Improvement of student learning outcomes can be seen from the average value of class $1^{\text {st }}$ cycle tests, cycle $2^{\text {nd }}$, and cycle $3^{\text {rd }}$ respectively 72,$38 ; 81,23 ; 85,83$ with classical mastery at cycle $1^{\text {st }}, 2^{\text {nd }}$, and $3^{\text {rd }}$ respectively that is $64,70 \%, 75,75 \%$, and $82,85 \%$.
\end{abstract}

Keywords: TAI Learning Model, LKPD, Scientific Approach and Learning Outcomes

PENDAHULUAN

Matematika adalah dasar dari semua disiplin ilmu. Oleh karena itu, matematika selalu dipelajari di setiap jenjang pendidikan di Indonesia mulai dari Sekolah Dasar (SD), Sekolah Menengah Pertama (SMP), Sekolah

Farah, Nurul, Syafdi 
Menengah Atas (SMA) dan Perguruan Tinggi. Selain itu, matematika merupakan ilmu universal yang mendasari perkembangan teknologi modern, mempunyai peranan penting dalam berbagai disiplin dan memajukan daya pikir manusia (Depdiknas, 2006:345).

Matematika dijadikan salah satu cabang ilmu yang sangat diperlukan dalam kehidupan manusia. Hal ini dikarenakan dalam pembelajaran matematika siswa dilatih agar dapat berpikir kritis, logis, dan sistematis. Matematika juga berperan dalam penyelesaian masalah kehidupan sehari - hari seperti menghitung, mengukur, menalar, dan lain-lain. Pentingnya matematika dalam kehidupan sehari hari serta eratnya hubungan matematika dengan cabang ilmu lainnya menyebabkan mata pelajaran ini harus diperhatikan, baik dalam pelaksanaan dan kurikulum yang diterapkan. Keberhasilan guru matematika diharapkan mampu menjadikan kegiatan pembelajaran matematika bermakna.

Faktor yang mempengaruhi keberhasilan belajar ada 8 yaitu peserta didik, pengajar, atmosfir pembelajaran, sarana dan prasarana, kurikulum, lingkungan, atmosfir kepemimpinan, dan pembiayaan (Hanafiah dan Suhana, 2010: 8-10). Proses pembelajaran dapat berlangsung dengan baik jika kedelapan faktor tersebut dapat dimaksimalkan penerapannya. Selanjutnya pada faktor pengajar, guru harus memiliki strategi pembelajaran sehingga peserta didik dapat belajar secara efektif dan efisien dalam proses pembelajaran.

Hasil penelitian awal di SMP Negeri 4 Kota Bengkulu kelas VIII.2 yang berjumlah 35 siswa yang terdiri dari 15 siswa laki-laki dan 20 siswa perempuan diperoleh data hasil belajar yang masih rendah. Rendahnya hasil belajar siswa ini dibuktikan dengan data hasil belajar siswa kelas VIII.2 pada nilai akhir tahun ajaran 2017/2018. Dari 35 siswa yang mengikuti ulangan, 19 orang siswa yang mencapai nilai di atas Kriteria Ketuntasan Minimal (KKM). Jadi, persentase siswa yang mencapai KKM sekitar
$54,28 \%$. Hal ini menunjukan bahwa hasil belajar yang diperoleh belum maksimal. Kenyataannya bahwa siswa belum mencapai KKM dan ketuntasan belajar klasikal yaitu $80 \%$.

Pelajaran matematika pada umumnya merupakan pelajaran yang harus dipahami bukan sekedar dihafalkan. Kurangnya kemampuan peserta didik tersebut perlu segera ditemukan solusinya. Penggunaan media pembelajaran seperti Lembar Kerja Peserta Didik (LKPD) menjadi salah satu alternatif untuk meningkatkan hasil belajar peserta didik. Penyajian LKPD dapat dikembangkan dengan berbagai macam inovasi. Terdapat berbagai macam inovasi baru yang dapat diterapkan dalam penulisan LKPD salah satu diantaranya memadukan LKPD dengan pendekatan saintifik. Adapun hal-hal yang dikembangkan dalam LKPD berupa materi bangun ruang sisi datar yang dijelaskan secara bertahap supaya peserta didik lebih mudah dalam memahaminya.

Pada LKPD disertakan latihan dengan langkah saintifik (mengamati, menanya, mengumpulkan data, mengasosiasi dan mengkomunikasi).

Selain itu, alternatif tindakan yang dapat ditawarkan yaitu mengganti model pembelajaran. Salah satu model pembelajaran yang dapat diterapkan adalah model pembelajaran kooperatif. Salah satu tipe model pembelajaran kooperatif adalah TAI (Team Assisted Individualized). Model TAI didasarkan pada keunggulan yang dimiliki pembelajaran kooperatif dan pembelajaran individual. Sejalan dengan pendapat Slavin (2016 : 191) bahwa pembelajaran matematika TAI merupakan pembelajaran kooperatif yang dikombinasikan dengan pembelajaran individual sehingga disebut juga bantuan individual dalam kelompok.

Model pembelajaran kooperatif tipe TAI (Team Assisted Individualized) adalah model pembelajaran kooperatif yang dikombinasikan dengan pembelajaran individual sehingga

Farah, Nurul, Syafdi 
disebut juga bantuan individual dalam kelompok (Slavin,2016: 191). Model ini digunakan agar peserta didik yang kurang memahami materi dapat bertanya dan berdiskusi dengan teman kelompoknya. Sedangkan, peserta didik yang telah memahami materi dapat membagi ilmu dan lebih memahami materi dengan membantu menjelaskan materi ke teman kelompoknya. Sehingga, kesuksesan kelompok dapat dilihat dari kekompakan siswa dan pemahaman materi tiap anggota kelompok.

Model kooperatif tipe TAI, menurut Slavin (2016:187) memiliki dasar pemikiran yaitu untuk mengadaptasi pengajaran terhadap perbedaan individual berkaitan dengan kemampuan siswa maupun mencapai prestasi belajar siswa.

Berdasarkan penjabaran tersebut, dapat disimpulkan bahwa model pembelajaran TAI dapat digunakan sebagai salah satu alternatif untuk mengatasi masalah diatas. Maka peneliti melakukan penelitian tindakan kelas yang berjudul "Penerapan Model Pembelajaran Kooperatif Tipe TAI Berbantuan LKPD Berbasis Saintifik Untuk Meningkatkan Hasil Belajar Matematika Kelas VIII.2 SMPN 4 Kota Bengkulu".

\section{METODE}

Penelitian ini digolongkan ke dalam penelitian tindakan kelas (PTK) yang dikenal dengan istilah Clasroom Action Research. Penelitian tindakan kelas dapat diartikan suatu kegiatan ilmiah yang dilakukan oleh guru di kelasnya sendiri dengan jalan merancang, melaksanakan, mengamati, dan merefleksikan tindakan melalui beberapa siklus secara kolaboratif dan partisipasi yang bertujuan untuk memperbaiki atau meningkatkan mutu proses pembelajaran di kelasnya (Kunandar,2012:45).

Menurut Arikunto,dkk (2014:17-20) terdapat empat langkah pelaksanaan PTK yaitu (1) perencanaan, (2) pelaksanaan, pengamatan, (4) refleksi.

\section{TEMPAT DAN WAKTU PENELITIAN}

Penelitian ini dilaksanakan di SMP Negeri 4 Kota Bengkulu, dan waktu penelitiannya pada bulan 19 Maret-14 Mei 2018 semester genap tahun ajaran 2017/2018.

\section{SUBJEK PENELITIAN}

Subjek penelitian ini adalah siswa kelas VIII.2 SMP Negeri 4 Kota Bengkulu 5yang berjumlah 32 siswa, terdiri dari 15 siswa lakilaki dan 20 siswa perempuan. Subjek penelitian ini diperoleh dari data nilai akhir semester ganjil matematika kelas VIII SMPN 4 Kota Bengkulu tahun ajaran 2017/2018 yang menunjukkan bahwa nilai rata-rata ujian akhir semester ganjil kelas VIII.2 masih dibawah KKM yang di tetapkan sekolah yaitu 75 .

\section{PROSEDUR PENELITIAN}

Penelitian yang dilaksanakan adalah Penelitian Tindakan Kelas (Classoom Action Research) yang dilaksanakan dalam 3 siklus. Setiap siklus terdiri dari empat tahap, yaitu 1) perencanaan (planning), 2) pelaksanaan (Action), 3) pengamatan (Observing), 4) refleksi (reflecting).

1. Perencanaan

Adapun perencanaan pelaksanaan Siklus I terdiri dari:

a. Menelaah silabus pembelajaran untuk setiap siklus

b. Membuat Rencana Pelaksanaan Pembelajaran (RPP) pokok bahasan bangun ruang sisi datar dan skenario setiap siklus pembelajaran.

c. Membuat dan menyusun materi untuk setiap siklus.

d. Membuat menyusun tugas-tugas untuk siswa berupa lembar latihan tes penempatan, latihan kemampuan, tes formatif yang diajarkan oleh siswa dengan soal - soal yang berstruktur.

e. Membuat dan mempersiapkan alat bantu pembelajaran.

f. Mempersiapkan soal tes akhir setiap siklus dan kunci jawabannya. 
2. Pelaksanaan

Pelaksanaan pembelajaran yang dilakukan pada penelitian ini berupa pembelajaran di kelaskegiatan yang akan dilakukan pada penelitian ini dapat di uraikan sebagai berikut:

a. Kegiatan Awal

1. Persiapan

a. Guru mengkondisikan kelas sebelum memulai pembelajaran.

b. Guru merumuskan tujuan pembelajaran.

2. Peningkatan motivasi

Guru memotivasi siswa dalam memanfaatkan sumber belajar.

3.Guru memberikan apersepsi

b. Kegiatan Inti

1. Siswa dikelompokan menjadi beberapa kelompok belajar.

2. Guru meminta siswa untuk mengamati permasalahan yang telah diberikan pada LKPD dan menanyakan kesulitan yang didapat.

3. Guru meminta siswa bertanya mengenai hal yang diamati pada kegiatan penagamatan sebelumnya.

4. Siswa bersama teman kelompoknya diberikan waktu 15 menit untuk mengisi LKPD pada bagian mengumpulkan informasi sesuai dengan permasalahan sebelumnya.

5. Guru membagikan kepada masing masing siswa lembar latihan kemampuan dan guru meminta siswa untuk mengerjakannya.

6. Saat Siswa mengerjakan latihan kemampuan, guru memberikan pengajaran pada tiap kelompok secara bergantian. Pengajaran dilaksanakan untuk menyampaikan kembali materi kepada siswa yang belum memahami penjelasan sebelumnya. Untuk siswa yang belum mendapatkan pengajaran kelompok dapat mengerjakan latihan kemampuan terlebih dahulu sambil menunggu giliran.

7. Setelah siswa mampu menyelesaikan latihan kemampuan maka hasil jawaban dikoreksi oleh anggota satu kelompok berdasarkan lembar jawaban yang diberikan oleh guru.

8. Guru memberikan tes formatif untuk dikerjakan secara individu dan dikoreksi oleh anggota kelompok lainnya.

9. Guru memberikan tes unit atau tes siklus untuk seluruh siswa.

c. Kegiatan Penutup

Siswa bersama guru menyimpulkan materi yang telah dipelajari.

d. Observasi atau Pengamatan

Tahap ini dilakukan saat proses pembelajaran sedang berlangsung. Pada penelitian ini digunakan lembar observasi aktivitas siswa mengenai pelaksanaan pembelajaran untuk meningkatkan aktivitas dan hasil belajar matematika siswa dengan model pembelajaran kooperatif tipe TAI.

e. Refleksi

Pada tahap ini dilakukan refleksi sekaligus analisis terhadap data - data yang telah diperoleh selama pembelajaran dan observasi. Kemudian direfleksikan untuk melihat kekuarangan - kekurangan yang ada. Mengkaji apa yang telah dan belum terjadi, mengapa bisa terjadi demikian dan langkah apa yang seharusnya dilakukan untuk perbaikan. Sehingga hasil refleksi dapat dijadikan langkah selanjutnya untuk merencanakan tindakan untuk siklus selanjutnya.

\section{INSTRUMEN PENELITIAN}

Widoyoko (2009: 45) menyatakan bahwa "tes adalah alat untuk melakukan pengukuran, yaitu alat untuk mengukur informasi karakteristik suatu objek. Tes yang dilakukan adalah tes akhir siklus berupa tes tertulis. Tes ini dilakukan untuk mengetahui hasil belajar

Farah, Nurul, Syafdi 
matematika siswa yang disusun berdasarkan tujuan pembelajaran khusus setiap akhir siklus. Hasil dari tes ini digunakan sebagai acuan untuk tindakan selanjutnya.

Selain itu, tes hasil belajar digunakan untuk memperoleh data tentang hasil belajar matematika siswa. Pada model pembelajaran kooperatif tipe TAI, hasil tes belajar berupa tes penempatan yang nilainya diambil dari tes akhir setiap siklus.

\section{TEKNIK ANALISIS DATA}

Lembar tes dianalisis dengan nilai individu, nilai rata-rata siswa, dan kriteria ketuntasan belajar berdasarkan penilaian tingkat daya serap siswa yang ditentukan berdasarkan ketetapan sekolah tersebut.

a. Nilai Rata-Rata Siswa

Nilai rata-rata hasil belajar siswa diperoleh dari nilai tes tiap siklus dengan rumus :

$$
\begin{array}{|c|}
\hline \bar{x}=\frac{\sum x}{N} \\
\text { Modifikasi Sudjana, 2016:109) }
\end{array}
$$

Keterangan :

$\bar{X}=$ Nilai rata-rata hasil belajar siswa

$\sum x=$ Jumlah nilai tes akhir siswa

$N=$ Jumlah tes

b. Ketuntasan Belajar Klasikal

$$
P=\frac{\sum \text { siswa yang tuntas belajar }}{\sum \text { seluruh siswa }} \times 100 \%
$$

Keterangan :

Sumber:Aqib,dkk(2014:41)

$P=$ penilaian ketuntasan belajar klasikal

Lalu, ketuntasan hasil belajar secara klasikal akan tercapai apabila $80 \%$ siswa memperoleh nilai $\geq 75$.

\section{INDIKATOR KEBERHASILAN}

Hasil belajar dikatakn meningkat minimal rata-rata klasikal telah mencapai KKM mata pelajaran matematika yaitu 75 dan siswa yang memperoleh nilai $\geq 75$ sebanyak $80 \%$.

\section{HASIL DAN PEMBAHASAN \\ HASIL}

\section{Kondisi Awal}

Berdasarkan hasil wawancara dan observasi, dapat dikemukakan gambaran umum permasalahan dalam proses pembelajaran matematika di kelas VIII.2 SMPN 4 Kota Bengkulu, diantaranya:

1. Pada proses pembelajaran, guru masih mendominasi kegiatan pembelajaran di kelas. Hal ini disebabkan pembelajaran di kelas masih sering menggunakan model pembelajaran ekspositori atau berpusat pada guru sehingga tercipta pembelajaran yang kurang optimal dan siswa menjadi pembelajar yang pasif.

2. Kurang adanya inovasi pembelajaran terutama pada penggunaan sumber belajar yang hanya berorientasi pada buku paket dan sedikit memberi peluang siswa untuk mengkonstruksikan ide - ide matematika mereka sendiri.

3. Saat pembelajaran matematika berlangsung siswa kurang memahami materi pembelajaran matematika. Hal ini dikarenakan siswa tidak berani untuk bertanya. Siswa lebih berani menanyakan permasalahannya dengan teman sebangku.

4. Siswa kelas VIII.2 kurang percaya diri saat mengerjakan tugas atau latihan, hal ini terlihat saat siswa mengerjakan soal dan masih meminta bantuan atau bahkan menyontek pekerjaan temannya

\section{Observasi Siklus I}

Hasil belajar menurut siklus I diperoleh nilai rata-rata siswa yaitu 72,38 . Jumlah siswa pada kelas VIII.2 adalah 35 dan yang masuk pada pertemuan tes siklus I hanya 34 orang siswa. Sehingga, presentase ketuntasan belajar klasikal yang diperoleh yaitu $64,7 \%$ artinya dari 34 orang siswa ada 22 orang yang mampu

Farah, Nurul, Syafdi 
mencapai nilai KKM yaitu minimal 75. Lalu, berdasarkan ketuntasan klasikal yang ditetapkan oleh sekolah yaitu $80 \%$ juga belum tercapai pada siklus 1 . Berdasarkan hasil tes siklus I diperoleh data sebagai berikut:

Tabel 1. Hasil belajar siswa Siklus I

\begin{tabular}{|c|c|}
\hline $\begin{array}{l}\text { Hasil Belajar } \\
\text { Siklus } 1\end{array}$ & $\begin{array}{l}\text { Hasil Tes } \\
\text { Siklus 1 } \\
\end{array}$ \\
\hline Nilai Tertinggi & 98,5 \\
\hline Nilai Terendah & 14 \\
\hline Nilai Rata-rata & 72,38 \\
\hline $\begin{array}{l}\text { Presentase } \\
\text { ketuntasan belajar } \\
\text { klasikal }\end{array}$ & $64,7 \%$ \\
\hline Median & 78,875 \\
\hline Standar Deviasi & 19,46 \\
\hline $\begin{array}{l}\text { Indikator } \\
\text { keberhasilan }\end{array}$ & $\begin{array}{l}\text { Belum } \\
\text { berhasil }\end{array}$ \\
\hline
\end{tabular}

\section{Refleksi Siklus I}

Hasil belajar yang belum tercapai pada siklus 1 adalah Presentase ketuntasan belajar klasikal yang diperoleh kelas VIII.2 yaitu $64,7 \%$ artinya masih kurang dari ketuntasan klasikal $80 \%$ yang ditetapkan sekolah.

\section{Observasi Siklus II}

Hasil belajar menurut siklus II diperoleh nilai rata-rata siswa yaitu 81,23 . Jumlah siswa pada kelas VIII.2 adalah 35 dan yang masuk pada pertemuan tes siklus 1 hanya 33 orang siswa. Sehingga, presentase ketuntasan belajar klasikal yang diperoleh yaitu $75,75 \%$ artinya dari 33 orang siswa ada 25 orang yang mampu mencapai nilai KKM yaitu minimal 75. Lalu, berdasarkan ketuntasan klasikal yang ditetapkan oleh sekolah yaitu $80 \%$ juga belum tercapai pada siklus II. Berdasarkan hasil tes siklus 1 diperoleh data sebagai berikut:

Tabel 2.Hasil belajar siswa Siklus II

\begin{tabular}{|l|l|}
\hline $\begin{array}{l}\text { Hasil Belajar Siklus } \\
\text { II }\end{array}$ & $\begin{array}{l}\text { Hasil Tes } \\
\text { Siklus II }\end{array}$ \\
\hline Nilai Tertinggi & 97,39 \\
\hline Nilai Terendah & 52,17 \\
\hline
\end{tabular}

\begin{tabular}{|l|l|}
\hline Nilai Rata-rata & 81,23 \\
\hline \begin{tabular}{l} 
Presentase $\begin{array}{l}\text { ketuntasan belajar } \\
\text { klasikal }\end{array}$ \\
\hline Median
\end{tabular} & $75,75 \%$ \\
\hline Standar Deviasi & 82,6 \\
\hline $\begin{array}{l}\text { Indikator } \\
\text { keberhasilan }\end{array}$ & $\begin{array}{l}\text { Belum } \\
\text { berhasil }\end{array}$ \\
\hline
\end{tabular}

\section{Refleksi Siklus II}

Hasil belajar yang belum tercapai pada siklus 1 adalah Presentase ketuntasan belajar klasikal yang diperoleh kelas VIII.2 yaitu $75,75 \%$ artinya masih kurang dari ketuntasan klasikal $80 \%$ yang ditetapkan sekolah.

\section{Observasi Siklus III}

Hasil belajar menurut siklus III diperoleh nilai rata-rata siswa yaitu 85,57 . Saat pelaksanaan tes, seluruh siswa kelas VIII.2 yang berjumlah 35 semuanya masuk. Sehingga, presentase ketuntasan belajar klasikal yang diperoleh yaitu $82,85 \%$ artinya dari 35 orang siswa ada 29 orang yang mampu mencapai nilai KKM yaitu minimal 75. Lalu, berdasarkan ketuntasan klasikal yang ditetapkan oleh sekolah yaitu $80 \%$ sudah tercapai pada siklus III. Berdasarkan hasil tes siklus III diperoleh data sebagai berikut:

Tabel 3. Hasil belajar siswa Siklus III

\begin{tabular}{|l|l|}
\hline $\begin{array}{l}\text { Hasil Belajar } \\
\text { Siklus III }\end{array}$ & $\begin{array}{l}\text { Hasil Tes } \\
\text { Siklus III }\end{array}$ \\
\hline Nilai Tertinggi & 100 \\
\hline Nilai Terendah & 59,87 \\
\hline Nilai Rata-rata & 85,87 \\
\hline $\begin{array}{l}\text { Presentase } \\
\text { ketuntasan belajar } \\
\text { klasikal }\end{array}$ & $82,85 \%$ \\
\hline Median & 87,26 \\
\hline Standar Deviasi & 11,11 \\
\hline $\begin{array}{l}\text { Indikator } \\
\text { keberhasilan }\end{array}$ & Berhasil \\
\hline
\end{tabular}

Farah, Nurul, Syafdi

Penerapan Model Pembelajaran Kooperatif Tipe Tai (Team Assisted Individualized) Berbantuan LKPD Berbasis Saintifik Untuk Meningkatkan Hasil Belajar Pada Siswa Kelas VIII.2 SMPN 4 Kota Bengkulu 


\section{PERBANDINGAN HASIL BELAJAR TIAP SIKLUS}

Lalu, Berdasarkan perbandingan data hasil tes setiap siklus, secara individu perkembangan hasil belajar siswa sangat beragam. Siswa kelas VIII.2 ada yang mengalami peningkatan nilai dan ada yang mengalami penurunan hasil belajar. Keberagaman tersebut dapat dilihat pada gambar 1 Berikut:

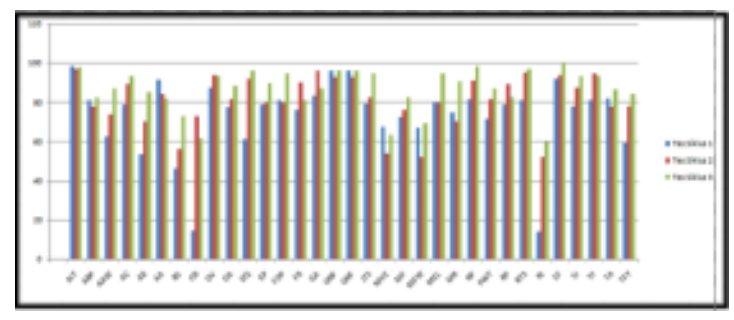

Gambar 1. Perkembangan nilai tes siklus siswa

Dari gambar diatas, terlihat bahwa perkembangan nilai siswa secara individu tidak selalu meningkat tiap siklusnya. Peningkatan nilai setiap siklus hanya terjadi pada 19 orang siswa $(57,14 \%), 1$ siswa $(5,71 \%)$ mengalami penurunan sedangkan 12 siswa $(37,14 \%)$ lainnya mengalami perubahan nilai yang naik turun. Artinya presentase siswa yang mengalami perubahan nilai yang naik turun dari siklus I hingga siklus III ada $22,85 \%$ dengan presentase siswa yang mengalami penurunan nilai dari siklus I ke siklus II ada 8 siswa dan penurunan nilai dari siklus II ke siklus III ada 4 siswa dengan peresentase $11,42 \%$.

Penurunan nilai tes pada siklus II yang terjadi pada 8 siswa diakibatkan kurang terlatihnya siswa membuat satuan pada jawaban soal. Guru harus lebih mengingatkan siswa secara rutin untuk teliti saat menjawab soal. Selain itu pada awal pembelajaran tes siklus III, guru melakukan ulasan mengenai kesalahan jawaban pada tes siklus II. Sehingga, adanya umpan balik yang dilakukan oleh guru. Lalu, pada siklus III ada 4 orang siswa yang mengalami penurunan nilai tes. Sama halnya dengan tes siklus II, siswa juga lupa saat menuliskan satuan sehingga mendapatkan pengurangan point pada tes siklus III.

Secara individu presentase siswa yang tidak pernah mencapai nilai ketuntasan belajar $\geq 75$ selama tes siklus I hingga siklus III adlah $17,14 \%$ atau 6 orang siswa. Hasil tes siklus III menunjukkan bahwa masih ada 6 orang siswa yang belum mencapai kriteria ketuntasan maksimal, adapun nilai tes siklus keenam siswa adalah BS; CN; DHM; MVE; MFW dan RI. Jika dilihat nilai siswa terendah pada siklus III yaitu 59,87 lebih tinggi dibandingkan pada tes siklus II yaitu 52,17.

\section{PEMBAHASAN}

Berdasarkan analisis tes siklus hasil tes siklus I terdapat 13 orang siswa yang belum mencapai KKKM (75). Siswa tidak tuntas dikarenakan siswa masih mengalami kesulitan dalam menganalisis maksud soal, siswa tidak teliti dalam melakukan perhitungan matematika, dan tidak mengerti menggunakan rumus luas permukaan kubus dan balok. misalnya pada soal nomor 5 sebanyak 12 siswa salah dalam menjawab soal. Siswa salah saat menggunakan rumus phytagoras. Sehingga jawaban yang didapat menjadi salah. Soal nomor 5 pada tes siklus I dapat dilihat pada gambar 2 berikut:

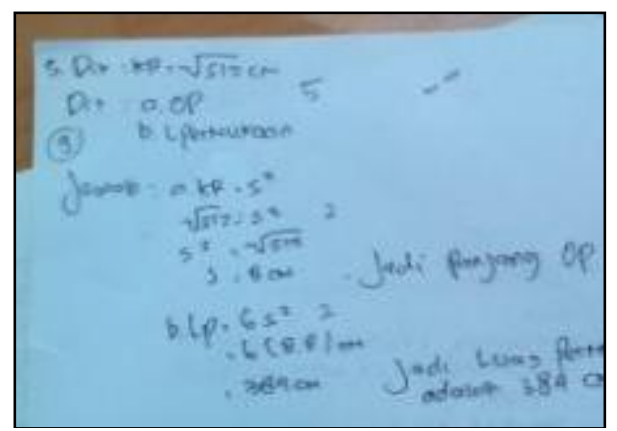

Gambar 2. Jawaban siswa tes siklus I nomor 5

Terlihat pada gambar diatas, siswa masih salah dalam menuliskan rumus. Siswa lupa bahwa panjang diagonal $\mathrm{KR}=2 \mathrm{~s}^{2}$. Sehingga, siswa tidak membagi $\sqrt{512}$ dengan 2 terlebih dahulu. Selain itu, siswa juga lupa

Farah, Nurul, Syafdi 
menuliskan satuan pada jawaban. Namun ada juga siswa yang berhasil menjawab soal nomor 5 dengan benar. Hal ini dapat dilihat pada gambar 3 berikut ini:

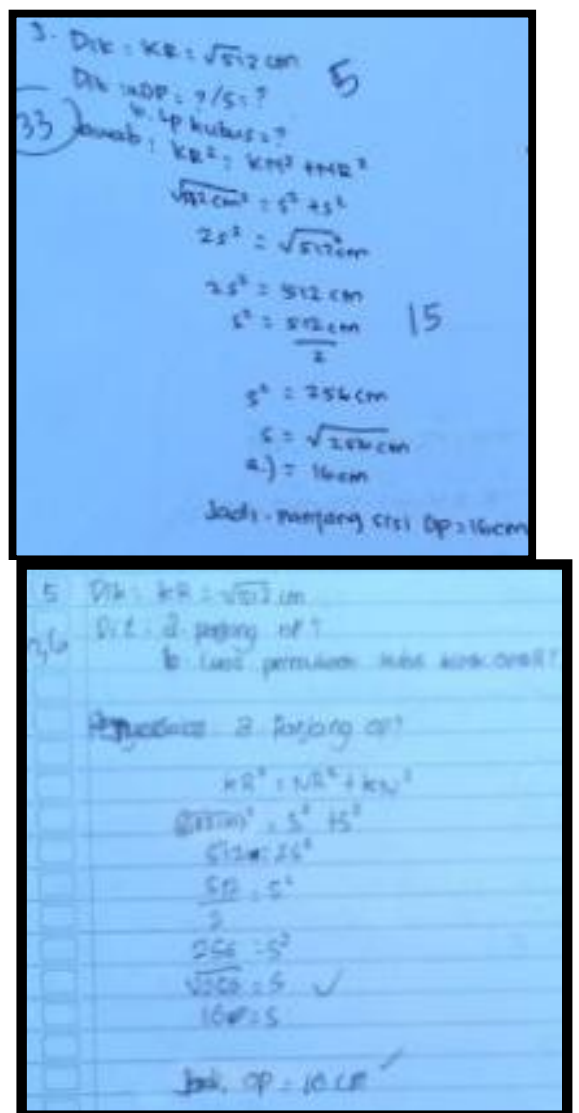

Gambar 3. Jawaban siswa tes siklus I nomor 5

Dari gambar, terlihat kedua siswa menjawab soal dengan benar. Siswa pertama menjawab soal dengan benar dan menulis setiap satuan pada setiap baris. Sedangkan siswa kedua menjawab soal dengan benar tetapi lupa menuliskan satuan pada jawaban. Sehingga siswa kedua mendapat pengurangan point pada tes siklus I.

Selanjutnya kesalahan siswa pada tes siklus I juga terjadi pada soal nomor 6. Siswa masih sulit dalam mengerjakaan soal, hal ini dikarenakan siswa kurang memahami rumus dari luas permukaan balok. Padahal pada pertemuan sebelumnya guru telah menekankan kepada siswa untuk mempelajari buku dan menyelesaikan latihan pada buku cetak bagian luas permukaan balok. Jadi, bagi siswa yang mendengarkan penjelas guru, dapat menjawab pertanyaan yang diajukan pada nomor 6 .

Lalu pada tes siklus II, kesalahan siswa menjawab soal paling banyak terjadi pada soal nomor 3. Kesalahan siswa dalam menjawab soal diakibatkan kurangannya waktu dalam menjawab soal, salah dalam menghitung dan tidak membuat satuan pada jawaban. Menurut peniliti, membuat satuan adalah hal yang penting dengan tujuan agar siswa dapat teliti dalam mengerjakan soal. Berikut kesalahan siswa saat mengerjakan soal pada tes siklus II:

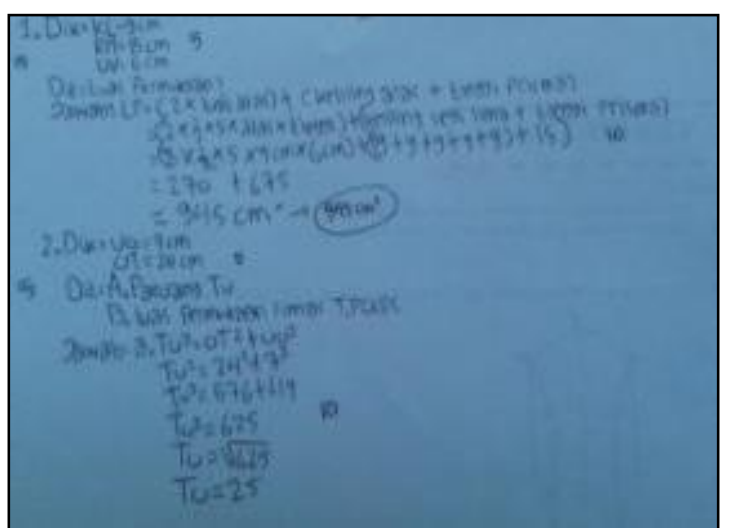

Gambar 4.Jawaban siswa tes siklus II nomor 3

Guru melakukan tindakan berupa lebih memotivasi siswa saat mengerjakan tes formatif. Selain itu, setelah siswa mengerjakan tes formatif maka guru memberkan kunci jawaban tes formatif agar siswa dapat belajar di rumah. Ketua kelompok juga diberi tugas untuk mengajarkan temannya yang belum memahami materi. Tindakan dalam membiasakan siswa melakukan tes formatif membuat siswa menjadi terbiasa dalam mengerjakan soal dan membuat satuan pada setiap jawaban.

Setelah dilakukan tindakan tersebut, maka pada siklus III diperoleh nilai rata-rata 85,83 dan masih ada 6 orang yang mendapatkan nilai dibawah KKM atau secara ketuntasan klasikal mencapai 82,85\%. Dari 4 soal essay yang diberikan pada siklus III ini, siswa paling banyak salah pada nomor 4 . Kesalahan masih terjadi dalam menghitung (tidak teliti) dan tidak membuat satuan. 
Kesalahan siswa saat mengerjakan soal pada tes siklus III dapat dilihat pada gambar 5:

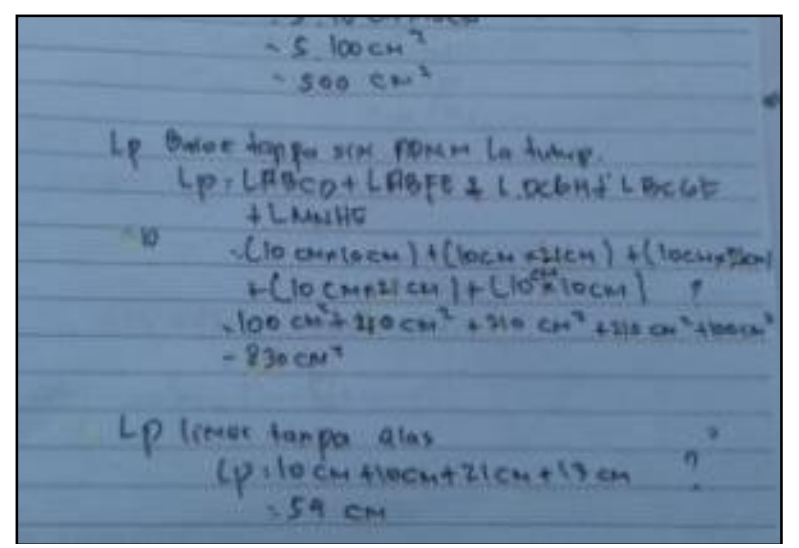

Gambar 5.Jawaban siswa Tes siklus III nomor 4

Berdasarkan data diatas menunjukan bahwa penerapan model kooperatif tipe TAI berbatuan LKPD berbasis pendekatan saintifik dapat meningkatkan hasil belajar siswa kelas VIII.2 SMPN 4 Kota Bengkulu. Hal ini sesuai dengan pendapat Hosnan (2014:36) yang mengatakan bahwa salah satu tujuan dari pendekatan saintifik adalah diperolehnya hasil belajar yang tinggi. Selain itu, Slavin (2016:48) mengatakan bahwa pembelajaran kooopertaif tipe TAI memiliki pengaruh tinggi terhadap pembelajaran atau kegiatan berhitung.

\section{KESIMPULAN DAN SARAN}

\section{KESIMPULAN}

Dari hasil penelitian yang telah
dilakukan dan pembahasan yang telah
diuraikan maka diperoleh kesimpulan
Pelaksanaan pembelajaran matematika dengan
penerapan model pembelajaran kooperatif tipe
TAI berbantuan LKPD berbasis saintifik dapat
meningkatkan hasil belajar siswa dengan cara :

a. Guru mengelompokan siswa secara heterogen sehingga siswa bekerja sama berdiskusi mengumpulkan informasi yang dibutuhkan dan bersama-sama mendiskusikan, memanfaatkan sumber belajar yang tersedia seperti halnya buku- buku matematika, alat peraga dan sebagainya pada siklus I.

b. Pada tes siklus II, guru meminta siswa untuk tetap belajar di rumah dan menyiapkan tes siklus dan guru juga meminta ketua kelompok bertanggung jawab atas pemahaman teman satu kelompoknya.

c. Memotivasi siswa yang belum tuntas nilainya, serta memberikan pembahasan atau kunci jawaban pada setiap latihan yang diberikan di siklus III.

d. Mengingatkan siswa untuk membuat satuan pada setiap jawaban agar tidak mendapatkan pengurangan point saat tes Siklus III.

Berdasarkan hasil tes siklus I,II, III menunjukan bahwa aktivitas belajar siswa meningkat dari Siklus I, Siklus II, dan Siklus III. Hal ini terlihat dari ketuntasan belajar klasikal siklus I yaitu $64,70 \%$ dengan 22 orang yang tuntas. Kemudian pada siklus II ketuntasan belajar klasikal meningkat menjadi 75,75 dengan 25 orang siswa yang tuntas dan ketuntasan belajar klasikal siswa mengalami peningkatan kembali menjadi $82,85 \%$ dengan 29 orang siswa yang tuntas.

\section{SARAN}

Berdasarkan penelitian yang telah dilakukan maka peneliti memberikan beberapa saran, yaitu :

1. Proses pembelajaran sebaiknya menggunakan alat peraga yang dibagikan pada setiap kelompok belajar. Sehingga siswa lebih mudah melakukan kegiatan mengamati dan mengumpulkan informasi pada LKPD.

2. Guru sebaiknya memberikan umpan balik saat siswa telah menyelesaikan dan mengoreksi latihan kemampuan. Hal ini bertujuan agar kegiatan kelompok belajar pada pertemuan selanjutnya dapat dilakukan dengan baik oleh siswa.

3. Guru harus rutin mengingatkan siswa untuk teliti menuliskan satuan pada setiap jawaban soal. Guru juga sebaiknya 
memberikan ulasan mengenai hasil belajar siswa persiklusnya.

\section{DAFTAR PUSTAKA}

Arikunto, dkk. 2014. Penelitian Tindakan Kelas. Jakarta : PT Bumi Aksara.

Aqib, dkk. 2014. Penelitian Tindakan Kelas untuk Guru SD, SLB dan TK. Bandung : CV. Yrama Widya.

Depdiknas. 2006. Kurikulum Tingkat Satuan Pendidikan (KTSP). Jakarta : Depatemen Pendidikan Nasional

Hosnan. 2014. Pendekatan Saintifik dan Kontekstual dalam Pembelajaran Abad 21. Bogor: Ghalia Indonesia

Meizha, dkk. 2014. Peningkatan Motivasi dan Hasil Belajar Matematika melalui Model Pembelajaran Kooperatif Tipe Team Assisted Individualisation. Jurnal Pendidikan Matematika, Vol 2 No 3,281-287.

Prastowo, Andi. 2013. Panduan Kreatif Membuat Bahan Ajar Inovatif. Yogyakarta: Diva Press.

Sardiman. 2014. Interaksi dan Motivasi Belajar Mengajar. Depok : PT Rajagrafindo Persada.

Saribun, dkk. 2013. Upaya Meningkatkan Aktivitas dan Hasil Belajar Siswa melalui Model Pembelajaran Tipe TAI dikelas VIII. Jurnal Pendidikan dan Pembelajaran: Vol 2 No 11: 1-13.

Slavin, E. Robert. 2016. Cooperative Learning. Bandung : Penerbit Nusa Media.

Sulastri. 2014. Pembelajaran Muatan Lokal Pendidikan Lingkungan Hidup dengan Model Pembelajaran Group Investigation untuk SMA/MA. Probolinggo: Jurnal Pendidikan Sains, Vol 2 No 1,12-17.

Farah, Nurul, Syafdi

Penerapan Model Pembelajaran Kooperatif Tipe Tai (Team Assisted Individualized) Berbantuan LKPD Berbasis Saintifik Untuk Meningkatkan Hasil Belajar Pada Siswa Kelas VIII.2 SMPN 4 Kota Bengkulu 